\title{
Kami Bali-Lampung: Politik Identitas Etnik Bali Migran dalam Masyarakat Multikultural Way Kanan, Lampung1
}

\section{Zainal Arifin ${ }^{2}$}

\begin{abstract}
Abstraksi
Artikel ini menjelaskan bagaimana politik identitas etnik yang dipraktikkan komunitas Bali migran di wilayah Lampung yang multikultural, dimana berbagai etnik di Indonesia bisa ditemukan dan bermukim di wilayah ini. Komunitas Bali bermigrasi ke Lampung melalui proses transmigrasi pada tahun 1963 akibat meletusnya gunung Agung. Salah satu pemukiman komunitas Bali migran tersebut ada di desa Bali Sadhar di Kabupaten Way Kanan Provinsi Lampung. Dalam beberapa kasus, komunitas Bali dengan sentimen identitas budaya Hinduisme Bali yang kuat acapkali mengalami konflik sosial dengan etnis lain disekitarnya terutama di wilayah pemukiman baru. Tetapi komunitas Bali (Sadhar) di Way Kanan Lampung justru hidup dengan harmonis dengan komunitas lain di sekitarnya. Temuan penelitian menunjukkan bahwa keberhasilan penyesuaian budaya dalam praktik politik identitas di kalangan komunitas Bali (Sadhar) ini dilakukan dengan meredefinisi nilai-nilai budaya (Hindu) yang mereka miliki sesuai dengan kondisi lingkungannya.
\end{abstract}

Kata kunci: politik identitas etnik, redefinisi nilai budaya, penyesuaian budaya, komunitas migran Bali.

\begin{abstract}
This article explains how the ethnic identity politics practiced by the Bali migrant community in the multicultural Lampung region, where various ethnic groups in Indonesia can be found and settled in this region. The Balinese community migrated to Lampung through the transmigration process in 1963 due to the eruption of Mount Agung. One of the migrant Bali community settlements is in the village of Bali Sadhar in Way Kanan Regency, Lampung Province. In some cases, Balinese communities with forceful sentiment of cultural identities of Bali Hinduism often experience social conflicts with other ethnic groups especially in the new settlement region. However, the Balinese (Sadhar) community in Way Kanan Lampung perform harmonious interactions with other ethnic groups in their surrounding communities. The research finding shows that the successfull practice of cultural conformity through identity politics among the Balinese migrant community (Sadhar) is achieved by redefining the cultural values of Hinduism that they might relate to adapt to different social and environmental conditions.
\end{abstract}

Keywords: ethnic identity politics, redefinition of cultural values, cultural conformity, the Balinese migrant community.

\section{A. Latar Belakang}

Pada tahun 1963, Gunung Agung yang ada di Kabupaten Karangasem, Provinsi Bali meletus. Dampak letusan ini membuat berbagai daerah yang ada di Kabupaten Karangasem dan beberarapa daerah di kabupaten disekitarnya mengalami kerusakan, sehingga penduduknya harus diungsikan dan dipindahkan. Salah satu bentuk penanganan bencana letusan Gunung Agung tersebut, yaitu melalui program transmigrasi ke berbagai daerah di Indonesia diantaranya ke kecamatan Banjit, Kabupaten Way Kanan, Provinsi Lampung. Upaya penanganan dampak bencana letusan Gunung Agung yang dilakukan pemerintah,

\footnotetext{
${ }^{1}$ Untuk kutipan atau sitasi artikel ini: Arifin, Zainal. 2020. "Kami Bali-Lampung: Politik Identitas Etnik Bali Migran dalam Masyarakat Multikultural Way Kanan, Lampung". Jurnal Pemikiran Sosiologi Vol 7 (1): 47-62

2 Jurusan Antropologi Sosial, FISIP, Universitas Andalas. Email: arifinzed@soc.unand.ac.id
} 
Jurnal Pemikiran Sosiologi Volume 7 No.1 2020

"Kami Bali-Lampung": Politik Identitas Etnik Bali Migran dalam Masyarakat Multikultural Way Kanan, Lampung Zainal Arifin

dilakukan melalui program yang dikenal dengan sebutan KOGA (Komando Operasi Gunung Agung).

\section{Adapun komunitas Bali yang ada} ditransmigrasikan ke wilayah Banjit ini berasal dari berbagai wilayah, diantara dari Karang Asem, Tabanan, Bangli, Singaraja, Kelungkung dan Nusa Penida. Komunitas Bali migran yang ada di Banjit ini berasal dari dari berbagai wilayah yang ada di Bali diantara, Karangasem (mendominasi Bali Sadhar Utara), Tabanan, Bangli dan Singaraja (mendominasi Bali Sadhar Tengah), Kelungkung dan Nusa Penida (mendominasi Bali Sadhar Selatan). Di wilayah transmigrasi ini (Banjit), mereka membangun pemukiman yang kemudian mereka namai Bali Sadhar yang berarti komunitas Bali yang sadar dan mau berpindah ke daerah lain (transmigrasi). Sekarang, secara administratif komunitas Bali Sadhar ini terkonsentrasi di 3 desa yaitu : (1) Desa Bali Sadhar Utara, (2) Desa Bali Sadhar Tengah, dan (3) Desa Bali Sadhar Selatan.

Pada saat ditransmigrasikan tahun 1963, di daerah Banjit ini sudah menetap beberapa etnis lain, seperti Lampung, Semende, Ogan, Jawa, Sunda dan Banten, yang sebahagian besar bermata pencaharian sebagai petani ladang. Kedatangan komunitas Bali ke wilayah Banjit ini, pada awalnya memunculkan kekhawatiran bagi sebahagian besar komunitas lokal disekitarnya. Salah satu kekhawatiran tersebut, dikarenakan Bali adalah komunitas yang memiliki identitas yang cukup kuat dengan ajaran Hindu nya, sementara komunitas lokal disekitarnya (khususnya Lampung, Semende dan Ogan) adalah komunitas penganut Islam yang taat. Pandangan masyarakat lokal bahwa komunitas Bali memang berbeda dengan "mereka", sampai sekarang masih dirasakan oleh sebahagian besar orang Bali di Bali Sadhar. Kekuatiran ini tidak saja diungkapkan oleh komunitas lokal dalam bentuk penilaian (sterotype) bahwa orang Bali Sadhar penyembah "berhala" dan mengkonsumsi babi, tetapi juga melahirkan prasangka (prejudice) yang mengakitbatkan komunitas Bali Sadhar ini cenderung terkucil dalam interaksi sosialnya. Kasus seperti ini sebenarnya tidak saja dialami oleh komunitas Bali (Sadhar), tetapi juga dialami banyak komunitas migran yang berbeda budaya yang ada di Lampung (Romli dan Ayu Maulia, 2011).

Kondisi ini tidak saja telah membuat komunitas Bali Sadhar merasa terasing di wilayah baru, tetapi juga merasa "prustasi" apakah mereka mampu bertahan dalam upaya memperbaiki ekonomi kehidupannya selama di daerah baru ini. Pada awalnya, kondisi ini diatasi dengan selalu berkomunikasi dengan kampung halaman di Bali dan komunitas Bali yang telah ada di beberapa daerah di Lampung. Pada perkembangan kemudian, beberapa tokoh masyarakat Bali Sadhar juga akhirnya membangun prasarana dalam bentuk bus yang digunakan sebagai transportasi bagi komunitas Bali Sadhar untuk pergi keberbagai daerah di daerah Lampung bahkan kemudian rute transportasi ini juga akhirnya sampai ke Bali. Cara ini cukup efektif untuk membuka keterasingan di daerah baru, sekaligus membangun kepercayaan diri, bahwa mereka "harus" menjadi Bali-Lampung. Ungkapan komunitas Bali Sadhar untuk menjadi Bali-Lampung ini lah yang kemudian dipopulerkan oleh pemandu wisata dengan sebutan little Bali in Lampung 
Jurnal Pemikiran Sosiologi Volume 7 No.1 2020

"Kami Bali-Lampung": Politik Identitas Etnik Bali Migran dalam Masyarakat Multikultural Way Kanan, Lampung Zainal Arifin

Secara budaya, bukan hal gampang bagi komunitas Bali Sadhar untuk membangun dirinya menjadi Bali-Lampung. Perbedaan budaya dan agama yang mereka miliki dengan komunitas lokal disekitarnya, sangat potensial menciptakan konflik dalam masyarakatnya. Akan tetapi sejak keberadaan mereka di daerah Banjit, justru konflik tersebut tidak sampai meletus menjadi konflik SARA di masyarakatnya. Keberhasilan ini tidak saja disebabkan karena adanya kesadaran dan dukungan semua komunitas etnis disekitarnya dalam menempatkan diri mereka sebagai masyarakat multikultural. Akan tetapi juga disebabkan karena kemampuan komunitas Bali Sadhar dalam menampilkan identitas nya yang serasi dengan identitas komunitas lokal di sekitarnya.

Berangkat dari pemikiran inilah, menarik untuk dipahami, bagaimana politik identitas yang terbangun di komunitas Bali Sadhar sehingga mereka tetap mampu menampilkan identitas dirinya, sekaligus mampu mengharmonikan nya dengan komunitas lokal disekitarnya. Artikel ini mencoba memberi gambaran tentang politik identitas yang dilakukan komunitas Bali Sadhar di wilayah masyarakat yang multikultural yang ada di Lampung. Ini tidak saja penting untuk memberi pemahaman kepada kita tentang strategi budaya komunitas migran di daerah baru, tetapi juga memberi gambaran kepada kita bagaimana politik identitas mampu mengharmonikan pola hubungan dan interaksi sosial di masyarakat multikultural.

\section{B. Metode Penelitian}

Artikel ini merupakan hasil kajian antropologis yang dilakukan penulis pada awal tahun 2019 yang lalu, di salah satu komunitas migran Bali yang ada di Kabupaten Way Kanan, Provinsi Lampung, khususnya di kecamatan Banjit.

Keberadaan komunitas migran Bali di wilayah ini terbentuk melalui proses transmigrasi tahun 1963, setelah Gunung Agung meletus. Komunitas migran Bali di wilayah Banjit Way Kanan sengaja dipilih dari banyak wilayah transmigrasi Bali lainnya, karena di wilayah ini, justru komunitas migran Bali mampu hidup harmonis dengan komunitas Lampung sebagai komunitas lokal, dan dengan komunitas etnis lainnya.

Sejak keberadaannya tahun 1963 di wilayah Banjit Way Kanan ini, pola hubungan antara komunitas migran Bali dengan komunitas etnis lainnya, khususnya dengan komunitas Lampung, justru belum pernah menunjukkan sifat berkonflik. Ini sedikit berbeda dengan keberadaan komunitas migran Bali lainya di wilayah Lampung, yang justru sering melahirkan letupan dan potensi konflik antar mereka (Lihat misalnya kajian Zulfa (2014); Romli (2014); Utami (2014); dan Karomani (2011)). 
Gambar 1. Relokasi Migran Bali di Provinsi Lampung

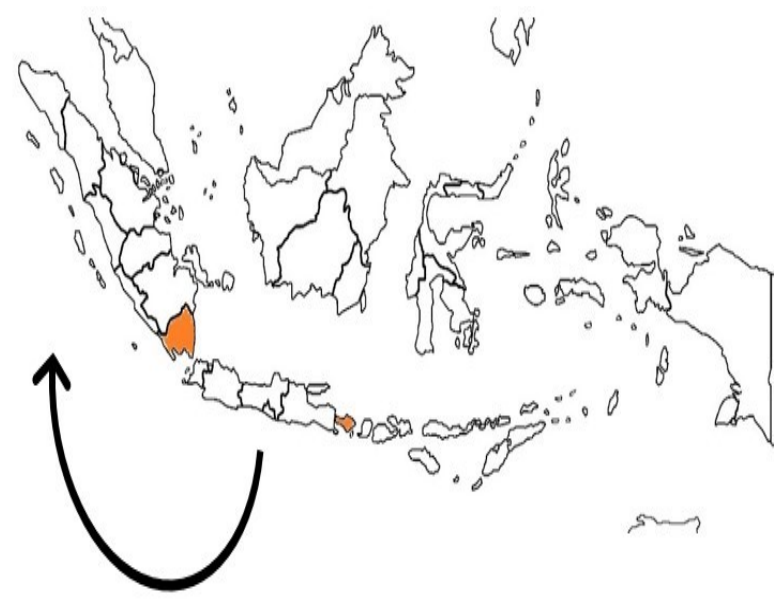

(Sumber: Arsip peneliti)

Penelitian ini sendiri menggunakan cara pandang antropologi kognitif, karena diasumsikan bahwa setiap komunitas mempunyai suatu sistem yang unik untuk mempersepsikan dan mengorganisasi fenomena kehidupan yang dihadapinya (Wassmann, 2015; Boster, 2012). Oleh sebab itu, berbagai kategori ditelusuri dan dianalisis termasuk kemungkinan akan hubungan antar kategori yang ada, sehingga menjadi sebuah informasi yang teritegrasi satu sama lain. Informasi yang diberikan setiap anggota komunitas Bali yang ada di Way Kanan ini, lebih dilihat sebagai individu yang telah mentransformasikan dirinya ke dalam suatu tahap cultural code, sehingga memunculkan individu sebagai penjelmaan pengalaman kelompoknya (Arifin, 2012). Melalui cara ini, maka pengetahuan yang mendalam tentang arti pentingnya identitas bagi komunitas migran Bali, dan bagaimana politik identitas tersebut dilakukan bisa ditemukan dengan baik.
Gambar 2. Lokasi Wilayah Pemukiman Baru (Transmigrasi) Komunitas Bali di Way Kanan, Lampung.

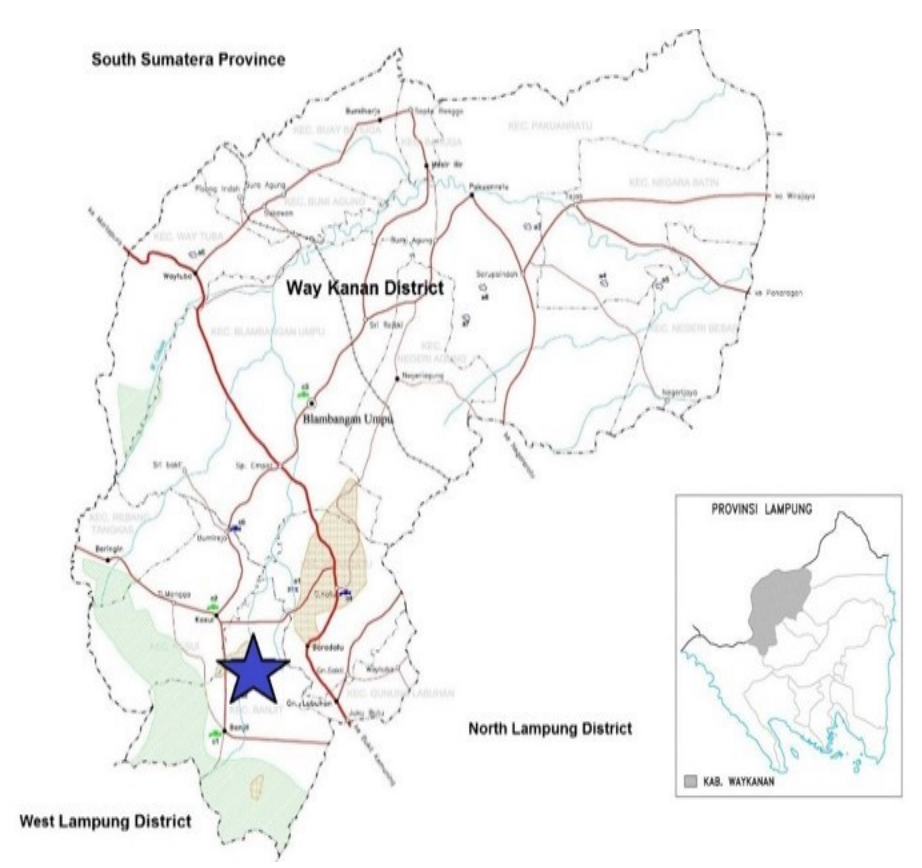

(Sumber: Arsip peneliti)

Berangkat dari pemikiran ini, maka sumber informasi utama terletak pada kekuatan informasi yang diberikan oleh komunitas migran Bali tersebut. Artinya interpretasi terhadap lingkungan dan komunitas sekitarnya akan dipahami sesuai dengan pola-pola pelaku itu sendiri (Keane, 2015). Adapun informasi tentang bagaimana politik identitas dilakukan komunitas migran Bali di kecamatan Banjit ini, didalami melalui wawancara dengan beberapa orang komunitas migran Bali yang ada di lokasi penelitian. Tidak ada pemilihan informan secara khusus, sehingga semua anggota komunitasnya diberi kesempatan untuk menjadi informan. Hal ini dilakukan dengan harapan mampu mendalami informasi secara menyeluruh tentang politik identitas etnik yang mereka lakukan. Hasil informasi ini lalu disandingkan dengan data observasi, dengan cara mengamati secara langsung 
Jurnal Pemikiran Sosiologi Volume 7 No.1 2020

"Kami Bali-Lampung": Politik Identitas Etnik Bali Migran dalam Masyarakat Multikultural Way Kanan, Lampung Zainal Arifin

bagaimana aplikasi politik identitas etnik yang terjadi di lapangan. Informasi dari lapangan inilah yang kemudian dianalisis dengan menggunakan pendekatan etnografis, sebagaimana tertuang dalam artikel ini.

\section{Tinjauan Teoritis: Politik Identitas Etnik dan Multikulturalisme}

Multikulturalisme adalah konsep yang sering digunakan para ahli untuk menegaskan pandangan akan adanya keragaman budaya dalam suatu masyarakat di areal tertentu. Keragaman ini akhirnya akan melahirkan pola interaksi khas antar komunitas dan etnis dengan budaya yang berbeda (Syaifuddin, 2006). Kata multiklulturalisme ini juga sering disandingkan dengan konsep pluralisme yang dimaknai sebagai pengakuan dan perlakuan suatu komunitas terhadap komunitas lain karena adanya perbedaan budaya tersebut. Pluralisme merujuk pada keadaan masyarakat yang terdiri atas berbagai suku, agama, asal, dan latar belakang budaya, tanpa melihat interaksi di antara mereka (Tanudirjo, 2011). Artinya, konsep pluralisme lebih menekankan pada aspek pemahaman atau cara pandang bahwa "kita berbeda dengan mereka".

Berbeda dengan konsep multikulturalisme yang lebih menekankan aspek ideologis berbangsa dan bernegara (kewarganegaraan). Sebagai ideologi maka multikulturalisme harus diperjuangkan karena menjadi landasan bagi tegaknya demokrasi, kesetaraan, HAM, dan kesejahteraan hidup masyarakatnya (Suparlan, 2002). Hal ini disebabkan karena konsep multikulturalisme lahir dari keyakinan bahwa setiap warganegara memiliki kesamaan kedudukan dalam masyarakatnya, sehingga setiap warga negara memiliki hak untuk tetap mempertahankan identitasnya, kebanggan akan asal usul dan nenek moyangnya (ancestry), serta rasa memiliki diri dan kelompoknya (Tanudirjo, 2011). Oleh sebab itu, dalam konteks harmonisasi, maka konsep multikulturalisme akhirnya lebih menekankan aspek politik dalam bentuk kebijakan terhadap perlindungan akan keberagaman tersebut (Setyaningrum, 2003; Wasino, 2013). Dimensi politik multikulturalisme ini akhirnya melahirkan pemikiran untuk menciptakan kerukunan, toleransi, saling menghargai perbedaan dan hak-hak masing-masing kebudayaan penyusun suatu bangsa.

Disamping aspek politis, multikulturalisme juga mengandung aspek kebudayaan, dimana kesadaran akan keberagaman dipahami sebagai hasil konstruksi sosial yang terbangun dalam relasi sosial antar komunitas etnis di dalamnya terkait dengan konsep kesetaraan dan ketidak-setaraan identitas (Setyaningrum, 2003). Ini menunjukkan bahwa pemahaman akan multikulturalisme, juga harus menyadari bahwa di dalamnya juga terkandung konsep destruktif dan konfrontatif, sehingga menciptakan konflik antar etnis, agama, dan golongan, serta menciptakan streotype dan prejudice tertentu tentang kelompok budaya tertentu, yang digambarkan baik melalui mitos, lelucon (jokes), dan cerita-cerita rakyat tertentu (folklore). Persoalannya, penekanan konsep multikulturalisme sebagai aspek politik dan kebudayaan ini - baik dalam konteks harmoni maupun destrultif - cenderung dipahami dalam konteks eksternal, yaitu sebagai hasil relasi sosial antar pelaku dan komunitas berbeda yang 
Jurnal Pemikiran Sosiologi Volume 7 No.1 2020

"Kami Bali-Lampung": Politik Identitas Etnik Bali Migran dalam Masyarakat Multikultural Way Kanan, Lampung Zainal Arifin

berinteraksi di dalamnya. Jarang sekali multikulturalisme dipahami dalam konteks internal, yaitu sebagai produk yang ada dan melekat dalam komunitas pelaku budaya itu sendiri.

Pemahaman multikulturalisme dalam
konteks eksternal, mengasumsikan bahwa keharmonisan dan konflik yang terjadi antar komunitas, lebih dilihat sebagai hasil persilangan pola hubungan yang terbangun dalam sebuah wilayah, dimana berbagai komunitas didalamnya tinggal dan melakukan interaksi. Menempatkan cara pandang multikulturalisme dalam konteks eksternal ini, akhirnya melahirkan dua kutup pemikiran yang berseberangan. Pertama, pemikiran bahwa setiap komunitas dalam suatu wilayah multikultural, perlu membangun pola hubungan demi tebangunnya persatuan (one culture). Kedua, pemikiran bahwa setiap komunitas dalam sebuah wilayah multikultural, perlu saling menghargai akan adanya keberagaman (many culture) (Miller, 1995).

Pemikiran akan pentingnya persatuan (one culture), berangkat dari asumsi bahwa perbedaan budaya berpotensi melahirkan konflik dan perpecahan, sehingga perbedaan antar budaya harus ditekan seminimal mungkin sehingga melahirkan identitas bersama. Sementara pemikiran akan keberagaman (many culture), berangkat dari asumsi bahwa setiap budaya memiliki entitas dan identitasnya sendiri yang tidak bisa disamakan dengan entitas dan budaya komunitas lain disekitarnya. Pentingnya membangun persatuan dalam konteks keragaman ini, akhirnya melahirkan tindakan akan perlunya konsensus, menumbuh-kembangkan sikap kerukunan dan solidaritas, serta membangun afiliasi silang antar etnis yang ada, sehingga diharapkan mampu menekan dominasi kelompok, dan meminimalisir potensi konflik yang akan terjadi. Tindakan ini tentu saja tidak bisa terbangun dengan sendirinya, karena ada kecenderungan setiap pemilik budaya tetap akan menunjukkan dan membangun identitasnya sendiri. Kondisi inilah yang akhirnya membuat upaya harmonisasi dan penyelesaian masalah antar etnis, memerlukan campur tangan negara.

Ada dua persoalan ketika multikulturalisme ditempatkan dalam konteks eksternal ini. Pertama, multikulturalisme sering dipahami dalam kaitannya dengan globalisasi. Artinya, globalisasi sering dianggap sebagai penyebab terjadinya perubahan identitas kultural setiap etnik, sehingga nilai-nilai "luhur" akan keharmonisan yang dibangun dalam budaya setiap etnik mengalami pengikisan dan kehancuran (Parekh, 2008). Kedua, multikulturalisme sering mengabaikan bahwa setiap komunitas etnik sebenarnya memiliki nilainilai budaya terkait dengan harmonisasi dan disharmonisasi (Suparlan, 2002). Artinya, secara internal dalam setiap etnik akan terkandung nilainilai budaya untuk selalu mengharmonisasikan diri dengan komunitas dan lingkungan sekitarnya, sekaligus juga mengandung nilai-nilai untuk selalu melakukan perlawanan dan sikap destruktif.

Berangkat dari pemikiran ini, maka memahami multikulturalisme dalam konteks internal yang ada dalam komunitas pemilik budaya tersebut akhirnya menjadi penting. Ini berangkat dari asumsi bahwa setiap komunitas cenderung akan selalu melakukan proses penyesuaian (conformity) dalam konteks interaksinya dengan 
Jurnal Pemikiran Sosiologi Volume 7 No.1 2020

"Kami Bali-Lampung": Politik Identitas Etnik Bali Migran dalam Masyarakat Multikultural Way Kanan, Lampung Zainal Arifin

lingkungan yang dihadapi (Spradley, 1987). Artinya, dalam setiap komunitas akan selalu memuat nilai budaya penyesuaian (cultural conformity) sebagai upaya mereka mempertahankan diri dari kepunahan dan kehancuran budaya dan komunitasnya. Sifat kompromi (conformity) ini tidak saja diujudkan bentuk berdamai dan melakukan konsensus dengan lingkungan sosial sekitarnya, tetapi juga bisa dilakukan dalam bentuk perlawanan yang bersifat destruktif. Ini menunjukkan bahwa setiap kelompok budaya sebenarnya memiliki strategi yang lentur (reservoir plasticity) yang akan dipakai oleh setiap kelompok dalam menghadapi kehidupan dan kelangsungan hidup mereka (Spradley, 1987).

\section{Proses penyesuaian (conformity) ini} dilakukan dengan cara mereproduksi identitas dan nilai budaya yang mereka miliki sesuai dengan kebutuhan lingkungan yang sedang dihadapi. Keberhasilan aktor dan kelompok dalam mereproduksi identitas ini, tidak bisa dilepaskan dari bagaimana mereka meredefinisi dan merekonstruksi identitas tersebut untuk memenangkan pertarungan (Arifin, 2018a; 2017). Disini konsep politik identitas etnik akhirnya menjadi relevan dalam memahami persoalan multikultural sebagai konsep internal pelaku budaya komunitas tersebut. Menurut Nicholson (2008), politik identitas bisa dipahami sebagai gerakan politik khas yang dilakukan komunitas dalam sebuah wilayah yang berbeda dengan komunitas lain di sekitarnya, dimana identitas pembeda tersebut bisa dalam bentuk tradisi (budaya), agama (kepercayaan), bahasa, gender, ekonomi, maupun politik (Abdillah, 2014). Politik identitas muncul sebagai bentuk "penyesuaian diri" komunitas terhadap kondisi lingkungan yang dihadapinya. Politik identitas, dimunculkan sebagai bentuk kesadaran komunal akan potensi mereka, dan memaksimalkannya dalam ujud perjuangan untuk mengatasi berbagai persoalan yang dihadapi. Melalui politik identitas ini, maka setiap komunitas akan merasakan solidaritas bersama dalam meujudkan eksistensi diri mereka.

Salah satu bentuk identitas komunal tersebut adalah identitas budaya yang biasanya berbasis etnik. Identitas budaya ini relatif cukup kuat untuk memunculkan dan mengikat solidaritas anggotanya, sehingga cenderung efektif untuk dipolitisasi sebagai sebuah gerakan politik (Tarakanita, 2013). Berangkat dari pemikiran ini, maka politik identitas etnik yang dimaksudkan disini adalah sebuah gerakan politik yang dilakukan komunitas etnik dalam mengatasi berbagai persoalan yang dihadapi dalam kehidupannya (Arifin, 2012; 2013). Sebagai sebuah gerakan, maka politik identitas etnik cenderung digunakan dan diujudkan dalam upaya mengorganisir identitas bersama dalam rangka memenangkan kekuasaan terhadap komunitas dan etnik lainnya. Sebagai identitas, maka budaya tersebut sifatnya khas dan hanya dimiliki oleh etnis tersebut, sehingga pengorganisasiannya relatif lebih efektif untuk memperjuangkan kepentingan bersama. Pengorganisasian identitas etnik ini dilakukan dengan cara meredefinisi dan merekonstruksi nilainilai budaya yang dimiliki, sesuai dengan kepentingan dan nilai yang diperjuangkan. Artinya, politik identitas etnik bukanlah berbasis nilai budaya lama, tetapi menggunakan nilai-nilai budaya 
Jurnal Pemikiran Sosiologi Volume 7 No.1 2020

"Kami Bali-Lampung": Politik Identitas Etnik Bali Migran dalam Masyarakat Multikultural Way Kanan, Lampung Zainal Arifin

yang sudah dikonstruksi oleh para pemilik budaya tersebut (Arifin, 2018b).

Politik identitas etnis tidak hanya ditujukan oleh komunitas etnis untuk menegosiasilan hak-hak sosial-budaya mereka yang dianggap termarginalkan (West-Newman, 2004; Sjaf, 2014), tetapi juga ditujukan untuk menegaskan eksistensi akan perbedaan budaya mereka dengan budaya komunitas lain disekitarnya (Hopkins, 2007). Artinya, politik identitas etnik lebih sebagai upaya untuk menuju kesetaraan antar budaya yang berbeda (principle of equality), bukan sebagai upaya untuk mencari persamaan budaya (principle of similarity). Pandangan ini penting, karena setiap budaya akan selalu berupaya untuk menunjukkan dan menguatkan identitasnya, dan berupaya untuk meminta legitimasi akan keberadaan mereka dalam kelompok budaya lain disekitarnya (Parekh, 2001). Upaya menguatkan dan meminta legitimasi ini, tidak saja melahirkan harmoni, tetapi juga membawa konsekuensi terjadinya konflik, dominasi, konfrontasi dan destruktif (May, 1999; Hintjens, 2001; O’Neill, 2003). Melalui pandangan ini, maka politik identitas etnik akan melahirkan konsepsi yang disebut Archer $(1985 ; 1982)$ sebagai koherensi logis (logical coherence) dan/atau dalam bentuk konsensus kausal (causal consensus). Dalam konteks ini, koherensi logis (logical coherence) dipandang sebagai kesesuaian secara internal antara berbagai elemen budaya yang mempengaruhinya. Sedangkan konsensus kausal (causal consensus) adalah tingkat keseragaman sosial yang dihasilkan karena adanya kesepakatan (consensus) bersama antar kelompok sosial berkenaan dengan komponen-komponen yang mempengaruhi.
Pandangan Archer tentang logical coherence dan causal consensus ini - yang dituangkan dalam teori morphogenesis-nya. Yakni yang berangkat dari pemikiran bahwa setiap individu maupun kelompok sosial memiliki kemampuan untuk menciptakan hubungan pertentangan (disharmoni) sekaligus menciptakan hubungan yang teratur (harmoni). Oleh sebab itu, keragaman konsepsi, gagasan dan perilaku yang berkembang pada setiap pelaku budaya dalam suatu komunitas budaya, telah "memaksa" (enforce) setiap anggota "meredefinisi" nilai-nilai budaya yang dimiliki untuk disesuaikan dengan nilai-nilai budaya lain, atau sebaliknya (Archer, 1982).

\section{D. "Kami Bali-Lampung": Politik Identitas Etnik Bali Migran}

Provinsi Lampung adalah salah satu provinsi di Indonesia yang penduduknya terdiri dari berbagai etnik. Menurut catatan BPS (2010), provinsi Lampung berjumlah 7.608.405 jiwa, yang tersebar kedalam berbagai etnis seperti Lampung $(13,51 \%)$ sebagai penduduk lokal, dan etnis pendatang seperti Jawa $(63,84 \%)$, Sunda $(9,58 \%)$, Ogan dan Semende (5,78 \%), Banten (2,27 \%), Bali $(1,38 \%)$, Minangkabau $(0,92 \%)$, Batak $(0,63 \%)$, Cina $(0,53 \%)$, dan Bugis $(0,28)$, disamping etnisetnis di Indonesia lainnya. Komposisi penduduk Provinsi Lampung yang sangat multikultural ini lebih disebabkan karena sampai menjelang berakhirnya penjajahan pemerintah kolonial Hindia Belanda, daerah Lampung dianggap sebagai daerah "tidak bertuan" (Kompas, 16 September 1996). Barulah pada 21 Juli 1939, etnis Lampung mulai 
Jurnal Pemikiran Sosiologi Volume 7 No.1 2020

"Kami Bali-Lampung": Politik Identitas Etnik Bali Migran dalam Masyarakat Multikultural Way Kanan, Lampung Zainal Arifin

memberlakukan kepemilikan lahan secara komunal (marga) berdasarkan Marga Reglement, No. 539/IGOB S.1938 No. 490 (Hadikusuma, 1990).

Kondisi masyarakat multikultural Lampung ini, tidak saja melahirkan keragaman budaya dan proses percampuran antar budaya dari berbagai etnis, tetapi juga rentan dengan konflik antar etnik yang ada. Salah satu wilayah yang mencerminkan masyarakat multikultural yang ada di Propinsi Lampung, bisa ditemui di beberapa kecamatan yang ada di Kabupaten Way Kanan, salah satu diantaranya adalah di kecamatan Banjit. Pada awalnya, Banjit adalah salah satu wilayah milik etnis Lampung yang dijadikan sebagai areal perladangan bagi komunitas migran di sekitarnya, yang umumnya berasal dari etnis Semende dan Ogan dari Sumatera Selatan. Pada perkembangan kemudian, akhirnya juga berdatangan etnis lain seperti Jawa, Sunda, Banten, dan Bali. Keragaman di wilayah Banjit ini tidak saja ditunjukkan dengan keragaman etniknya, tetapi juga keragaman agamanya yaitu Islam, Kristen dan Hindu. Ada kecenderungan, setiap etnis mengelompok dan mendiami sebuah wilayah tersendiri, sehingga masing-masing etnik tetap membawa identitas budayanya masingmasing, dan selalu berusaha untuk menguatkan dan meminta pengakuan akan identitas yang mereka miliki. Walaupun demikian, sampai sekarang masyarakatnya tetap bisa hidup saling berdampingan secara damai.

Kecamatan Banjit terbentuk sejak tahun 1972, dimana sebelumnya adalah salah satu desa yang ada di kecamatan Kasui. Salah satu komunitas etnis yang mendiami wilayah Banjit ini adalah komunitas etnik Bali, yang secara administratif mendiami 3 desa dari 20 desa yang ada (BPS, 2017). Keberadaan komunitas etnis Bali di Lampung bermula dari transmigrasi yang dilakukan tahun 1963, akibat meletusnya Gunung Agung, dan salah satu wilayah transmigrasi tersebut adalah di Kecamatan Banjit. Di wilayah transmigrasi Banjit ini, mereka terkonsentrasi ke dalam sebuah pemukiman yang kemudian mereka namai Bali Sadhar yang berarti komunitas Bali yang sadar dan mau (rela) berpindah ke daerah lain (transmigrasi). Walaupun, komunitas Bali Shadar ini berasal dari berbagai wilayah seperti dari Karangasem, Tabanan, Bangli, Singaraja, Kelungkung dan Nusa Penida, akan tetapi mereka memiliki kesadaran bersama sebagai etnis (orang) Bali.

Salah satu idenditas etnis Bali Shadar bisa dilihat dari agama yang dianutnya yaitu Hindu. Agama ini menjadi identitas khas karena ajaran Hindu dalam komunitas Bali, dipahami tidak sekedar sebagai ajaran agama, tetapi lebih sebagai adat (budaya) yang harus diterapkan dalam kehidupannya. Sebagai ajaran agama, maka Hindu lebih diposisikan sebagai nilai-nilai spiritual yang melingkupi kehidupan masyarakat dalam hubungannya dengan Tuhan nya. Sementara sebagai adat (budaya), maka Hindu lebih diposisikan sebagai nilai-nilai yang mempedomani komunitasnya dalam berkehidupan sehari-hari. Penempatan Hindu sebagai adat (budaya) dalam masyarakat inilah yang kemudian melahirkan istilah Hindu Bali, yang bermakna bahwa ajaran Hindu yang diterapkan komunitas Bali memiliki filosofi yang berbeda dengan Hindu di daerah lain, termasuk di daerah asalnya di India. 
Jurnal Pemikiran Sosiologi Volume 7 No.1 2020

"Kami Bali-Lampung": Politik Identitas Etnik Bali Migran dalam Masyarakat Multikultural Way Kanan, Lampung Zainal Arifin

Bagi masyarakat Bali Sadhar, ajaran Hindu ini dipahami adalah ajaran yang memuat filosofi keseimbangan dalam menjalankan kehidupan (tri hata karana). Filofosi keseimbangan hidup ini diaplikasikan dalam bentuk pola hubungan antara manusia dengan Tuhannya, antara Manusia dengan Lingkungannya dan antara manusia dengan manusia lainnya. Pola keseimbangan antara manusia dengan Tuhannya, diaplikasikan dalam bentuk selalu menyakini bahwa akan keberadaan Brahmana, Wisnu dan Siwa (tri murti) yang mengendalikan kehidupan manusia di dunia. Sementara keseimbangan antara manusia dengan lingkungan, diaplikasikan dalam bentuk selalu menjaga keseimbangan lingkungan dengan memanfaatkannya sesuai dengan peruntukan. Sedangkan keseimbangan pola hubungan antar manusia diaplikasikan dalam bentuk saling menghargai dan menghormati orang lain. Kesadaran akan filosofi keseimbangan yang bersumber dari ajaran Hindu ini lah, yang kemudian sangat mempengaruhi bagaimana komunitas Bali Shadar menjalani kehidupannya.

Komunitas Bali Shadar menyadari bahwa filosofi ajaran Hindu tentang keseimbangan ini, tentu saja akan berbeda aplikasinya sesuai dengan ruang dan waktu. Artinya, ketika ajaran Hindu ini diterapkan di Bali, maka aplikasinya akan berbeda ketika ia diaplikasinya di Bali Shadar, dan sangat memungkinkan juga berbeda ketika diaplikasi di daerah lain yang ada di Lampung. Kondisi sosiokultural masyarakat disekitarnya, kondisi lingkungan, ekonomi dan politik yang melingkupinya, sangat mempengaruhi bagaimana nilai-nilai filosofi dalam ajaran Hindu tersebut akan dilaplikasikan. Ini misalnya tercermin dalam struktur sosial komunitasnya yang sebahagian besar berasal dari kasta Sudra, secara ideal tidak memungkinkan untuk mengangkat seorang pemimpin agama (dari kasta Brahmana) sebagaimana dilakukan di Bali. Akan tetapi, keberadaan pemimpin agama justru sangat dibutuhkan dalam konteks pola hubungan manusia dengan Tuhannya.

Pola meredefinsi dan merekonstruksi budaya sesuai dengan kondisi lingkungan sekitarnya ini juga tercermin dalam upacara yang dilaksanakan dan tata cara pelaksanaannya, yang sangat disesuaikan dengan kondisi ekonomi, ketersediaan sumberdaya alam dan kondisi sosialbudaya Bali Shadar. Setiap upacara yang dilakukan akan membutuhkan banyak biaya, sehingga tidak semua keluarga akan mampu melaksanakannya. Upacara pembakaran mayat (ngaben) misalnya, setiap keluarga di Bali Shadar relatif akan mengeluarkan biaya sekitar 100 juta. Sebagian besar biaya ini digunakan untuk pembelian dan pembuatan benda-benda dan sesajen upacara, bahkan diantaranya harus didatangkan langsung dari Bali seperti kayu cendana, kain sutra Bali dan uang kepeng, karena ketiadaan benda upacara tersebut di daerah Lampung. Penempatan setiap upacara sebagai aktivitas yang sakral, membuat tidak semua benda upacara juga bisa digunakan, walaupun benda upacara tersebut ada dan ditemukan di wilayah Lampung. Kain sutra Bali misalnya, walaupun di Lampung bisa didapatkan kain sutra dengan motif yang bisa dipesan, tetapi karena nilai sakralnya berbeda, membuat kain sutra tersebut memang harus dipesan langsung ke Bali. 
Jurnal Pemikiran Sosiologi Volume 7 No.1 2020

"Kami Bali-Lampung": Politik Identitas Etnik Bali Migran dalam Masyarakat Multikultural Way Kanan, Lampung Zainal Arifin

Begitu juga dengan kondisi sosial-budaya masyarakat Bali Shadar dan masyarakat disekitarnya, juga membuat tata cara dalam melaksanakan upacara juga mengalami redefinsi dan rekonstruksi. Komunitas Bali Shadar berasal dari berbagai daerah di pulau Bali, yang secara umum terkelompok dalam tradisi Bali Aga dan Bali Majapahit. Walaupun komunitas Bali Shadar yang berasal dari daerah dua tradisi ini menganut ajaran agama yang sama yaitu Hindu, tetapi tidak semuanya memiliki kesamaan budaya terkait dengan tradisi berkehidupan. Oleh sebab itu, komunitas Bali Shadar menyadari bahwa tidak semua tradisi Bali Aga maupun Bali Majapahit harus dilakukan di komunitasnya. Begitu juga kondisi sosial-budaya masyarakat di sekitar Bali Shadar yang sebahagian besar Muslim, juga ikut mempengaruhi redefinsi dan rekonstruksi upacara dan tata cara berkehidupan yang mereka lakukan.

Salah satu upacara yang sebenarnya dianggap penting oleh komunitas Bali Shadar adalah upacara makan bersama sebagai tanda syukur dan pengikat kebersamaan (mengibung). Nilai sakral dari upacara mengibung adalah rasa kebersamaan diantara anggota dan pesertanya (sela), yang ditunjukkan dengan cara makan di dulang atau makan bersama di atas nampan yang sama dengan anggota sekitar 6 sampai delapan orang. Idealnya, mengibung tidak hanya ditujukan untuk komunitas etnis Bali saja, tetapi juga ditujukan untuk komunitas non-Bali. Akan tetapi, karena sebagian komunitas di sekitar Bali Shadar adalah Muslim (Islam), maka mengibung cenderung hanya dilakukan oleh sebahagian kecil keluarga di komunitas Bali Shadar saja, bahkan mulai jarang dilakukan sebagai kegiatan bersama dalam komunitasnya.

Gambar 3. Kolase Foto Kehidupan Komunitas Migran Bali di Provinsi Lampung
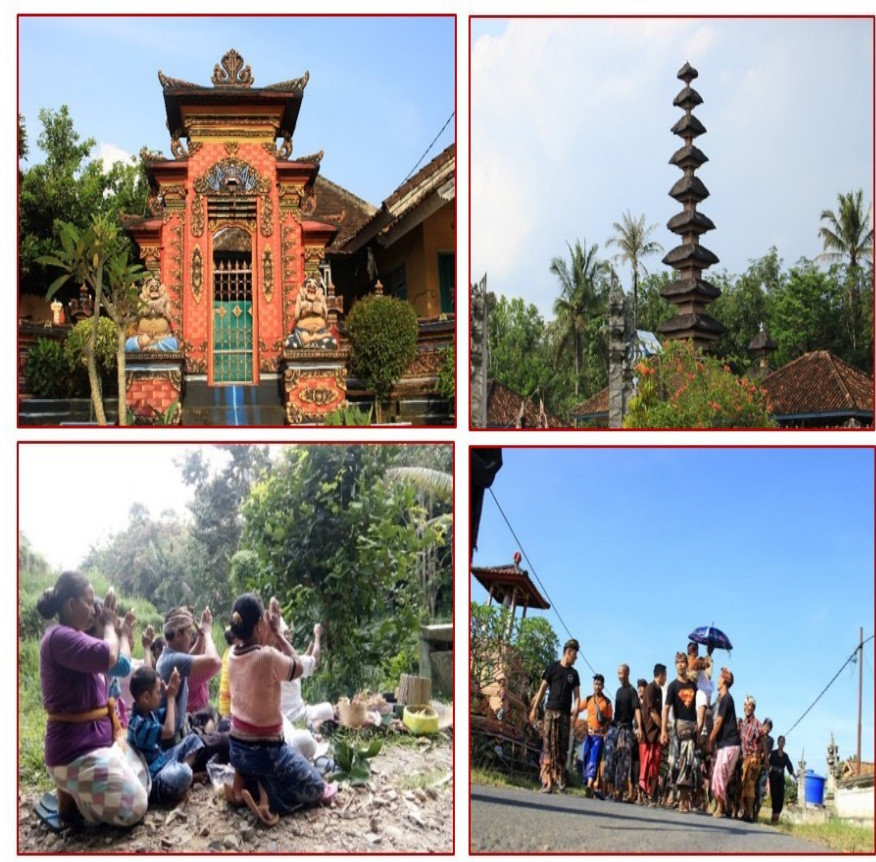

Sumber: Arsip Peneliti.

Proses redefinsi dan rekonstruksi tata cara dan pelaksanaan upacara-upacara di Bali Shadar ini, membuat hanya upacara-upacara penting saja yang cenderung masih dilakukan oleh komunitas Hindu Bali Shadar tersebut. Upacara-upacara penting tersebut lebih dalam bentuk upacara yang terkait langsung dengan kehidupan mereka di Bali Shadar, seperti upacara mensucikan hati dan pikiran (melasti), upacara rasa syukur dan meminta keselamatan (tumpek), upacara pembakaran mayat (ngaben), disamping upacara dalam rangka hari raya Nyepi. Sementara upacara-upacara lain yang cenderung hanya sebagai tradisi dalam kehidupan, maka mulai jarang bahkan tidak dilakukan lagi. Misalnya upacara persembahan atau pengorban sebagai bukti akan pengabdian yang tulus (ngurek), 
Jurnal Pemikiran Sosiologi Volume 7 No.1 2020

"Kami Bali-Lampung": Politik Identitas Etnik Bali Migran dalam Masyarakat Multikultural Way Kanan, Lampung Zainal Arifin

upacara pemberian bekal dan mengantar roh ke alam nirwana (mesuryak), pada awal-awal keberadaan mereka di Bali Shadar, masih sempat dilakukan, tetapi sekarang mulai tidak dilakukan lagi. Bahkan upacara potong gigi tanda kedewasaan bagi seseorang (mepandes), walaupun masih dilakukan, tetapi mulai jarang dilakukan di komunitas Bali Shadar ini.

Bagi komunitas Hindu di Bali Shadar, melakukan redefinsi dan rekonstruksi dalam setiap upacara ini, lebih dipahami sebagai salah satu ajaran Hindu terkait dengan keharusan melakukan keseimbangan dalam berkehidupan. Artinya, filosofi tersebut tidak sekedar dipahami dalam konteks ajaran agama, tetapi yang terpenting bagi komunitasnya adalah diaplikasikan dalam kehidupan. Filosofi keseimbangan tersebut, tidak hanya merupakan wujud perilaku sosial antar sesama orang Bali, tapi juga dalam hubungannya dengan etnis non-Bali disekitarnya. Tidak hanya diaplikasikan dalam hubungan antar manusia, tetapi juga dalam hubungannya dengan lingkungan sekitar. Bagi komunitas Bali Shadar, kesadaran untuk mengamalkan filosifi inilah, yang membuat mereka tetap eksis dan harmonis di daerah Banjit, tanpa memunculkan perpecahan, konflik, dan halhal lain yang menimbulkan dampak buruk bagi mereka.

\section{E. Kesimpulan}

Proses redefinisi dan rekonstruksi nilai-nilai budaya di komunitas Bali Shadar ini, tidak hanya dilakukan dalam konteks upacara saja, tetapi juga dilakukan dalam aspek-aspek kehidupan lainnya.
Proses redefinisi dan rekonstruksi bukanlah sesuatu hal yang baru dalam komunitas Bali. Pure (pura) misalnya sebagai tempat utama dalam menjalankan ajaran Hindu, sebenarnya adalah hasil penyederhanaan dari berbagai sekte yang dahulunya pernah ada di Bali (Arjawa, 2014). Menurut Arjawa, proses penyederhanaan ini sudah dilakukan sejak abad ke 11, ketika seorang tokoh agama Hindu Bali pada waktu itu (Mpu Kuturan) melihat potensi perpecahan dan dan konflik diantara umat Hindu di Bali. Akhirnya pure yang awalnya berdasarkan sekte-sekte, lalu disederhanakan menjadi hanya dua saja, yaitu pure keluarga dan pure komunal (bersama). Proses penyederhanaan ini dianggap bukan sesuatu yang salah, karena nilai-nilai budaya penyederhanaan untuk tujuan menjaga keseimbangan adalah hal yang paling penting dalam ajaran Hindu tersebut. Ini menunjukkan bahwa proses redefinisi dan rekonstruksi nilai-nilai budaya yang dilakukan komunitas Bali memang sudah termuat dalam nilainilai budaya mereka sendiri.

Kasus komunitas Bali Shadar menunjukkan bahwa proses redefinisi dan rekonstruksi dimunculkan dan dilakukan ketika dihadapkan dengan kondisi yang berbeda, yang memaksa komunitas ini melakukan proses penyesuaian budaya (cultural conformity). Proses penyesuaian ini tidak saja membuat mereka mampu mempertahankan eksistensi diri di daerah migran, tetapi juga mampu menunjukkan identitas ke-Baliannya. Proses penyesuaian ini tidak saja mampu maredam pertentangan dan konflik terbuka dengan komunitas di sekitarnya, tetapi juga mampu berkolaborasi secara politik dan ekonomi di tengah 
Jurnal Pemikiran Sosiologi Volume 7 No.1 2020

"Kami Bali-Lampung": Politik Identitas Etnik Bali Migran dalam Masyarakat Multikultural Way Kanan, Lampung Zainal Arifin

beragam etnis dan perbedaan. Keberhasilan komunitas Bali Shadar ini lebih disebabkan karena di dalam nilai-nilai budaya yang mereka miliki sudah terkandung nilai-nilai untuk melakukan proses penyesuaian (cultural conformity), yaitu filosofi untuk selalu menjaga keseimbangan dalam berkehidupan. Nilai-nilai budaya inilah yang kemudian secara lentur (reservoir plasticity) mereka gunakan dalam menghadapi berbagai persoalan yang di lingkungannya.

Ini menunjukkan bahwa, setiap etnis sebenarnya selalu ingin menunjukkan dan mempertahankan identitas budayanya, karena identitas tersebut sudah tertanam sebagai bagian dalam nilai-nilai budayanya. Kasus Bali Shadar ini juga menunjukkan bagaimana politik identitas etnik yang dilakukan setiap komunitas, mampu menciptakan pola harmoni. Ini berbeda dengan beberapa kasus di wilayah di provinsi Lampung lainnya, dimana keragaman budaya justru melahirkan konflik dan pertentangan (Karomani, 2011; Romli, 2014; Utami, 2014). Praktik multikulturalisme dalam masyarakat di Banjit justru menunjukkan bahwa keragaman yang dihasilkan bukan berbentuk penyatuan akan perbedaan budaya dalam masyarakatnya, tetapi justru menunjukkan kesetaraan antar etnik dimana satu sama lain saling menghargai. Hal ini bisa terjadi karena masing-masing etnik memiliki nilai-nilai penyesuaian diri (cultural conformity) agar selalu bisa harmoni dan saling menghargai satu sama lainnya.

Kasus masyarakat Banjit ini juga membuktikan bahwa di dalam konsepsi multikulturalisme sebenarnya juga terkandung nilai-nilai dimana setiap kelompok sebenarnya memiliki kearifan lokal tersendiri dalam menempatkan dan menghargai budaya kelompok lain (Ganap, 2012). Pola untuk selalu saling menghargai ini, sebenarnya akan selalu ditemui dalam setiap budaya komunitas, karena mereka akan selalu dihadapkan dengan dualisme antara konflik dan harmoni (Arifin, 2013). Pada satu sisi, konflik memungkinkan akan terjadi, karena setiap komunitas selalu berupaya untuk menunjukkan dan mempertahankan identitas budayanya, selalu berupaya menunjukkan perbedaan dan ketidaksamaan dirinya dengan kelompok lain. Namun pada sisi lain, setiap kelompok juga selalu berupaya untuk menciptakan harmoni dengan saling menghargai dan saling melengkapi.

\section{Daftar Pustaka}

Abdillah, Ubed. 2014. Politik Identitas. Pergulatan Tanda Tanpa Identitas. Jakarta : YOI

Al-Fairusy, Muhajir. 2015. “Model Konsensus Dan Rekonsiliasi Konflik Antar-Umat Beragama Di Aceh Singkil”, dalam Jurnal Al-Ijtima “i, 1(1)

Archer, M.S. 1985. "The Myth of Cultural Integration". The British Journal of Sociology, 36 (3): 333-353.

Archer, M.S. 1982. “Morphogenesis versus Structuration. On Combining Structure and Action". The British Journal of Sociology, 33(4): 455-483. 
Jurnal Pemikiran Sosiologi Volume 7 No.1 2020

"Kami Bali-Lampung": Politik Identitas Etnik Bali Migran dalam Masyarakat Multikultural Way Kanan, Lampung

Zainal Arifin

Arifin, Zainal. 2018a. Politik Perkawinan. Dualitas

Praktik Sosial Masyarakat Minangkabau.

Yogyakarta : Histokultura Graha Ilmu.

Arifin, Zainal. 2018b. Tunggu Tubang. Pola Kekuasaan dan Penguasaan Sumberdaya di Komunitas Semende Sumatera Selatan. Padang : CV Rumah Kayu Pustaka Utama.

Arifin, Zainal. 2017. "Nagari Ba-Ampek Suku. Politicisation Mythical Origins of Minangkabau", The Eastern Anthropologist, 70(1-2): 177-189.

Arifin, Zainal. 2013. "Bundo Kanduang (hanya) Pemimpin di Rumah (gadang)", Jurnal Antropologi Indonesia, 36(2): 124-133.

Arifin, Zainal. 2012. "Buru Babi : Politik Identias Laki-Laki Minangkabau", Jurnal Humaniora, 24(1): 29-36.

Arjawa, GPB Suka. 2014. "Identitas Kepemilikan Pura dalam Hubungannya dengan Perkembangan Pariwisata dan Konflik Sosial di Bali”. Jurnal Masyarakat, Kebudayaan dan Politik, 27(3): 137-148.

Boster, James S. 2012. “Cognitive Anthropology Is a Cognitive Science". Topics in Cognitive Science, 4: 372-378.

BPS. 2011. "Kewarganegaraan, Suku Bangsa, Agama, dan Bahasa Sehari-Hari Penduduk Indonesia." Hasil Sensus Penduduk 2010. Jakarta : BPS.

BPS. 2017. Kecamatan Banjit dalam Angka. Blambangan Umpu : BPS Kabupaten Way Kanan.
Ganap, Victor. 2012. "Konsep Multikultural dan Etnisitas Pribumi dalam Penelitian Seni". Jurnal Humaniora, 24(2): 156-167.

Haboddin, Muhtar. 2012. “Menguatnya Politik Identitas di Ranah Lokal". Jurnal Studi Pemerintahan, 3(1): 116-134.

Hadikusuma. 1989. Masyarakat dan Adat Budaya Lampung. Bandung : Mandar Maju.

Haryanto, Joko Tri. 2012. "Interaksi dan Harmoni Umat Beragama". Jurnal Walisongo, 20(1): 211-234.

Hefner, Robert W. 2007. Politik Multikultural. Yogyakarta: Penerbit Kanisius.

Hintjens, Helen M. 2001. “When Identity Becomes a Knife : Reflecting Genocide in Rwanda". Journal Ethnicites, 1(1): 25-55.

Howe, Leo. 2005. The Changing World of Bali. Religion, Society and Tourism. London and New York : Routledge.

Karomani. 2011. "Persepsi Dan Prasangka Antaretnik Di Lampung Selatan: Studi Komunikasi Antar Etnik Di Bakauheni Kalianda”. Jurnal Sosiohumaniora, 13(1): 3940.

Keane W. 2015. "Why Cognitive Anthropology Needs to Understand Social Interaction and Its Mediation". Social Anthropology, 23(2):192193.

Kukathas, Chandran (eds). 1993. Multicultural Citizens. The Philosophy and Politics of Identity. Sydney: The Centre for Independent Studies. 
Jurnal Pemikiran Sosiologi Volume 7 No.1 2020

"Kami Bali-Lampung": Politik Identitas Etnik Bali Migran dalam Masyarakat Multikultural Way Kanan, Lampung

Zainal Arifin

May, Stephen. 1999. “Critical Multiculturalism and Cultural Difference: Avoiding Essentialism", dalam May, Stephen (ed). Critical Multiculturalism: Rethinking Multicultural and Antiracist Education. London: UK Falmer Press.

Miller, David. 1995. On Nationality. Oxford: Oxford University Press.

Mudana, I Wayan. 2012. “Modal Sosial dalam Pengintegrasian Etnis Tionghoa Pada Masyarakat Desa Pakraman di Bali". Jurnal Ilmu Sosial dan Humaniora, 1(1): 30-40.

Nicholson, Linda. 2008. Identity Before Identity Politics. Cambridge: Cambridge University Press.

O'Neill, Shane. 2003. "Justice in Ethnically Diverse Societies : A Critique of Political Alienation". Journal Ethnicities, 3(3): 369-392.

Parekh, Bhikhu. 2001. Rethinking Multiculturalism: Cultural Diversity and Political Theory. Cambridge, Mass.: Harvard University Press.

Romli, Khomsahrial \& Maulia, Ayu. 2014. "Prasangka Sosial Dalam Komunikasi Antaretnis (Studi Antara Suku Bali dengan Suku Lampung di Kecamatan Sidomulyo Kabupaten Lampung Selatan Provinsi Lampung)". Jurnal Kom \& Realitas Sosial, 4(2): 127-151.

Roth, Dik. 2011. "The Subak in Diaspora: Balinese Farmers and the Subak in South Sulawesi". Journal Humam Ecology, 39: 55-68

Setyaningrum, Arie. 2003. "Multikulturalisme Sebagai Identitas Kolektif, Kebijakan Politik dan Realitas Sosial", Jurnal Ilmu Sosial dan Ilmu Politik, 7(2): 243-260.

Sjaf, Sofyan. 2014. Politik Etnik, Dinamika Politik Lokal di Kendari. Jakarta : YOI

Spradley, J.P and D.W. McCurdy. 1987. Conformity and Conflict. Reading in Cultural Anthropology (6th edition). Boston \& Toronto: Little, Brown and Company.

Suparlan, Parsudi. 2002. "Menuju Masyarakat Indonesia yang Multikultural". Jurnal Antropologi Indonesia, 69(3): 98-105.

Syaifuddin, Achmad Fedyani. 2006. "Membumikan Multikulturalisme di Indonesia". Jurnal Etnovisi, 2(1): 3-11.

Tanudirjo, Daud Aris. 2011. Membangun Pemahaman Multikulturalisme: Perspektif Arkeologi. Paper Workshop Multikulturalisme dan Integrasi Bangsa dalam Pembangunan Kebudayaan dan Pariwisata, di Kusuma Sahid Prince Hotel, Solo tanggal 5 Mei 2011 (Tidak dipublikasikan).

Tarakanita, Irene \& Cahyono, Maria Yuni Megarini. 2013. "Komitmen Identitas Etnik dalam Kaitannya dengan Eksistensi Budaya Lokal". Jurnal Zenit, 2(2): 98-105.

Utami, Anisa. 2014. "Resolusi Konflik Antar Etnis di Kabupaten Lampung Selatan (Studi Kasus: Konflik Suku Bali Desa Balinuraga Dan Suku Lampung Desa Agom Kabupaten Lampung Selatan)". Journal of Politics And Government Studies, 3(2): 1-23. 
Wasino. 2013. "Indonesia: From Pluralism to Multiculturalism." Jurnal Paramita, 23(2): 148-155.

West-Newman, Catherine Lane. 2004. "Anger, Ethnicity, and Claiming Identity". Journal Ethnicities, 4(1): 27-52.

Yanti, Ketut Leni \& Ali Imron \& Suparman Arif. 2014. "Perkawinan Beda Kasta pada Masyarakat Balinuraga di Lampung Selatan". Jurnal Pendidikan dan Penelitian Sejarah, 2 (2)

Zulfa, Eva Achjani. 2014. "Bali Nuraga Lampung: Identity Conflict Behind The Policy". Jurnal Hukum Internasional Law, 11(2): 261-283.

Wassmann, Jürg and Andrea Bender. 2015. "Cognitive Anthropology," dalam Wright, James D (ed), International Encyclopedia of the Social \& Behavioral Sciences (Second Edition). Orlando: University of Central Florida. 